\title{
Protected environments and substrates for production of genipap seedlings
}

\author{
Adriano Ribeiro SASSAQUI ${ }^{1}$, Tainara Ferreira da Silva TERENA ${ }^{2}$, Edilson COSTA ${ }^{3}$
}

ABSTRACT

Genipap (Genipa americana L., Rubiaceae) is a native Brazilian species and can be used in the recovery of degraded forest areas or for food supply. In order for the species to reach its potential, production of high quality seedlings is essential. The objective of this study was to evaluate genipap seedlings in protected environments and different substrates. The environments tested were: (1) a greenhouse with polyethylene film in the top, with aluminized screen (Aliminet) of 50\%-shading under this film, and lateral sides covered with 50\%-shading nylon net (Sombrite), (2) a shaded hut, all sides covered with 50\%-shading nylon net (Sombrite), and (3) a nursery shelter, with all lateral sides uncovered and the roof covered with leaves of buriti (Mauritia flexuosa). In these environments the following substrates were tested: $50 \%$ cattle manure $+50 \%$ cassava foliage, $50 \%$ cattle manure $+50 \%$ Vida Verde, $50 \%$ cattle manure $+50 \%$ vermiculite, and $25 \%$ cattle manure $+25 \%$ vermiculite $+25 \%$ of cassava foliage $+25 \%$ Vida Verde. Because there was no repetition of the growth environment, the effect of environment was examined using statistical procedures for analysis of combined experiments. Within environments a completely randomized design was used with five replications. All substrates are suitable for the formation of genipap seedlings, where the recommended substrates are: $50 \%$ cattle manure $+50 \%$ cassava foliage and 50\% cattle manure $+50 \%$ Vida Verde for the greenhouse and the substrates composed of $50 \%$ cattle manure $+50 \%$ vermiculite and $25 \%$ cattle manure $+25 \%$ cassava foliage $+25 \%$ Vida Verde $+25 \%$ vermiculite for the shaded hut. The buriti shelter is not recommended for production of genipap seedlings.

KEYWORDS: Genipa americana, cattle manure, cassava foliage, analysis of combined experiments.

\section{Ambientes protegidos e substratos para formação de mudas de jenipapeiro}

\section{RESUMO}

O jenipapo (Genipa americana L., Rubiaceae) é uma espécie brasileira nativa e pode ser utilizada na recomposição de áreas de florestas degradadas ou fornecimento de alimentos. Para que a espécie atinja elevado potencial, a produçáo de mudas de elevada qualidade é essencial. O objetivo deste estudo foi avaliar mudas de jenipapo em ambientes protegidos e diferentes substratos. Os ambientes testados foram; (1) uma estufa agrícola com filme de polietileno transparente na cobertura, com tela aluminizada (Aliminet ${ }^{\circ}$ ) de 50\% de sombreamento sob este filme, e lateral com tela de 50\% de sombreamento; (2) uma cabana sombreada com todos os lados cobertos com tela de nylon de 50\% de sombreamento (Sombrite), e (3) um abrigo com todas as laterais sem fechamentos e cobertura com folhas de buriti (Mauritia flexuosa). Nestes ambientes foram testados os substratos $50 \%$ esterco bovino + 50\% rama de mandioca, 50\% esterco bovino + 50\% Vida Verde , 50\% esterco bovino + 50\% vermiculita e $25 \%$ esterco bovino $+25 \%$ vermiculita $+25 \%$ rama de mandioca $+25 \%$ Vida Verde . Por não haver repetição do ambiente de cultivo, o efeito do ambiente foi examinado usando procedimento estatístico para análise de experimentos combinados. Dentro dos ambientes um delineamento experimental inteiramente casualizado foi utilizado com cinco repetiçóes. Todos os substratos são indicados para formação de mudas de jenipapeiro, sendo recomendados os substratos a base de $50 \%$ esterco bovino $+50 \%$ rama de mandioca e $50 \%$ esterco bovino $+50 \%$ vida verde para a estufa agrícola e os substratos com $50 \%$ de esterco bovino $+50 \%$ vermiculita e $25 \%$ esterco bovino $+25 \%$ rama de mandioca $+25 \%$ vida verde $+25 \%$ vermiculita para a cabana sombreada. O abrigo com buriti náo é recomendado para produção de mudas de jenipapo.

PALAVRAS-CHAVE: Genipa americana, esterco bovino, ramas de mandioca, análise de experimentos combinados.

\footnotetext{
1 Universidade Estadual de Mato Grosso do Sul (UEMS/Aquidauana-MS). Curso de Pós-Graduação em Agronomia. Rodovia Aquidauana/UEMS, km 12, CX P. 25, CEP. 79200-000 Aquidauana-MS, adrianosassaqui@hotmail.com

2 UEMS, Aquidauana-MS, tainara_terena@hotmail.com;

${ }^{3}$ UEMS/Cassilândia - MS, mestrine@uems.br.
} 


\section{INTRODUCTION}

Genipap (Genipa americana L., Rubiaceae), a native Brazilian species, is distributed throughout the Brazilian territory; it reaches 8 to $14 \mathrm{~m}$ in height and a diameter of 0.4 to $0.6 \mathrm{~m}$ (Lorenzi 2000). Leaves are large and oblong, and the flowers are large and bloom from November to December. The sexual method is predominantly used for the formation of seedlings with a high percentage of emergence, about 83 to $92 \%$ (Ferreira et al. 2007), but the germination process is considered slow (Nascimento and Carvalho 1998).

Genipap is considered a culture of economic potential (Souza 2007). Its fruits can be used for making liqueurs and jams due to their acidic and pungent aroma (Rizzini and Mors 1995). The genipap not only presents economic potential as a function of the fruit, but presents great ecological importance in the recovery of riparian forests because it is resistant to flooding (Lorenzi 2000).

Substrate quality is one of the factors that influences the formation of genipap seedlings (Andrade et al. 2000). Thus the components used in the formulation may alter germination (Andrade et al. 2000) and final quality of seedlings (Costa et al. 2005). Mesquita et al. (2009) reported that the use of "soil + manure + carbonized rice straw" and "manure + vermiculite" met the nutritional demands for quality seedlings. Costa et al. (2005) also noticed that the base substrate of black soil and manure (1:1), and black soil, rice hulls and manure (1:1:1) are efficient for propagation of genipap seedlings.

There is a lack of studies on the effects of environments on genipap. Thus, the objective of this study was to evaluate the production of genipap seedlings in different substrates and protected environments at Aquidauana, Mato Grosso do Sul, Brazil.

\section{MATERIALS AND METHODS}

This work was conducted at the experimental area of the Universidade Estadual de Mato Grosso do Sul (UEMS), Aquidauana Campus, which is located at $174 \mathrm{~m}$ above

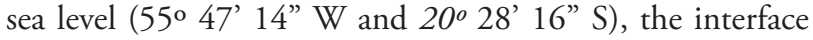
region between the Brazilian Cerrado and Pantanal ecotones; during the months of September 2010 to January 2011. The climate of the regions is Aw according to the Köppen classification, defined as tropical and humid with average annual temperature of $29^{\circ} \mathrm{C}$.

Genipap seedlings (Genipa americana L. Rubiaceae) seedlings were developed from seeds in different environments, defined as (Figure 1): (1) greenhouse ( $8.0 \mathrm{~m}$ wide by $18.00 \mathrm{~m}$ long and $4.00 \mathrm{~m}$ height), zenith opening at the top, covered with transparent low density polyethylene film of $150-\mu \mathrm{m}$ thickness and transmittance of 70 to $80 \%$ of solar radiation, with aluminized screen (Aliminet ${ }^{\circ}$ ) of 50\%-shading under this film, with the lateral and front sides of the structure enclosed with 50\%-shading nylon net (Sombrite) ; (2) shaded hut (8.0 $\mathrm{m}$ wide by $18.00 \mathrm{~m}$ long and $3.50 \mathrm{~m}$ height), all sides covered with 50\%-shading nylon net (Sombrite) and (3) a nursery buriti shelter constructed using a wood framework ( $3.00 \mathrm{~m}$ long by $1.20 \mathrm{~m}$ wide by $1.80 \mathrm{~m}$ height); the roof covered with leaves of buriti (Mauritia flexuosa), and with all lateral sides uncovered.

Inside the protected environments the seedlings were germinated in 1.8-L-polyethylene bags $(15.0 \times 25.0 \mathrm{~cm})$. In these environments the following substrates were tested (S1) $50 \%$ cattle manure $+50 \%$ cassava foliage, (S2) $50 \%$ cattle manure $+50 \%$ Vide Verde , (S3) 50\% cattle manure $+50 \%$ vermiculite and (S4) $25 \%$ cattle manure $+25 \%$ vermiculite $+25 \%$ cassava foliage $+25 \%$ Vida Verde (Table 1 ). Genipap seeds were collected from trees in the region of AquidauanaMS, Brazil, on September 18, 2010.

Cassava foliage was ground in a hammer mill (TRAPP, TRF 650, Jaraguá do Sul - SC - Brazil) to pass through an 8-mm-sieve; then it was composted for 30 days. Medium texture commercial vermiculite was purchased to make up the substrate.

The seeds were planted in polyethylene bags on September 27, 2010, two seeds were planted per bag. Forty days after planting, one of the seedlings was removed. After seeding
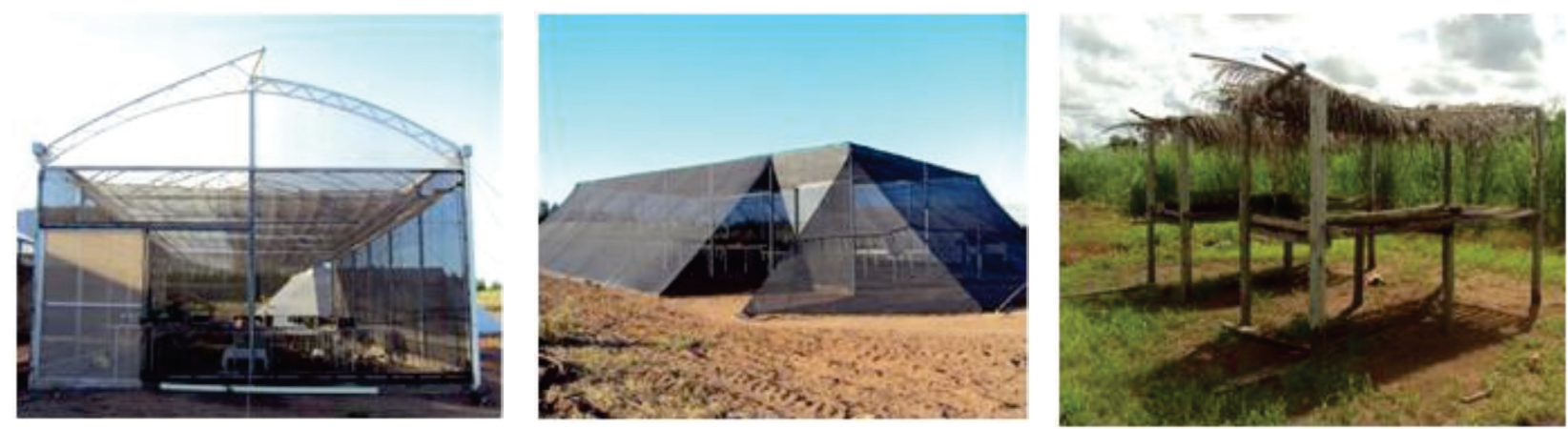

Figure 1 - Protected environments used in the experiment. Greenhouse (left panel), shaded hut (middle panel) and buriti shelter (right panel) 
Table 1 - Chemical analysis of the organic materials used in the experiments. Aquidauana, September 27, 2010 to January $28,2011$.

\begin{tabular}{|c|c|c|c|c|c|c|c|c|}
\hline & \multicolumn{8}{|c|}{----------------------------------------- g kg' } \\
\hline & $\mathrm{N}$ & $\mathrm{P}$ & K & $\mathrm{Ca}$ & $\mathrm{Mg}$ & S & C & $\mathrm{OM}$ \\
\hline $\mathrm{CM}$ & 9.30 & 1.82 & 1.00 & 4.95 & 0.90 & 1.07 & 112.00 & 192.00 \\
\hline $\mathrm{CF}$ & 26.70 & 6.62 & 29.00 & 27.45 & 7.70 & 3.25 & 483.00 & 830.00 \\
\hline \multirow[t]{3}{*}{ VV } & 4.20 & 0.77 & 2.00 & 5.60 & 6.20 & 2.46 & 217.00 & 373.00 \\
\hline & - & - & - & & -------- & $\mathrm{mg} \mathrm{kg}^{-1}$---- & ------- & \\
\hline & $\mathrm{pH}$ & U & $\mathrm{C} / \mathrm{N}$ & $\mathrm{Cu}$ & $\mathrm{Zn}$ & $\mathrm{Fe}$ & $\mathrm{Mn}$ & $B$ \\
\hline CM & 7.10 & 14.12 & 12.04 & 14.00 & 103.00 & 6000.00 & 239.50 & 12.19 \\
\hline CF & 8.80 & 65.04 & 18.09 & 16.50 & 170.00 & 910.00 & 223.00 & 28.75 \\
\hline VV & 5.10 & 15.76 & 51.67 & 31.00 & 47.00 & 10300.00 & 129.00 & 22.31 \\
\hline
\end{tabular}

* Laboratory of soil analysis (Solanalise), Dourados, $\mathrm{MS}$, Brazil. $\mathrm{OM}=$ organic material; $\mathrm{U}=$ moisture in $\%$ at $65^{\circ} \mathrm{C} ; \mathrm{CM}=\mathrm{cattle}$ manure; $\mathrm{CF}=\mathrm{cassava}$ foliage; $\mathrm{VV}=\mathrm{Vida}$ Verde ${ }^{\circledR} ; \mathrm{C} / \mathrm{N}=$ carbon to nitrogen ratio.

and at the beginning of emergence the following parameters were evaluated: emergence velocity index (EVI), percentage of emergence (EP), mean emergence time (MET) and mean emergence rate (MER).

The dry bulb and wet bulb temperatures were measured daily at 09:00, 12:00 and 15:00 h in each growth environment during the experiment. Relative humidity and vapor-pressure deficit were determined using the Psychrometric Function Demo software (Table 2).

Five measurements of plant height $(\mathrm{PH})$ were performed and leaf number (LN) counted, beginning on November 29, 2010, 63 days after sowing (DAS). The other measurements of height and leaf number were performed at 78, 93, 108 and 123 DAS.

At 123 DAS the stem diameter (SD) and dry matter of the shoot (DMAP) and root system (DMRS) were determined. The DMAP and DMRS were aggregated to obtain the total dry mass (TDM). From these measurements the following ratios were calculated: height to stem diameter (RHD), shoot dry matter to root dry matter (RDM), height to total dry mass $(\mathrm{RHDM})$ and Dickson quality index (DQI), where DQI = $[\mathrm{TDM} /(\mathrm{RHD}+\mathrm{RDM})]$.

Because there was no replication for the growth environment, each one was considered an experiment; we used a completely randomized design with five replications, each replication with five seedlings. Data were first submitted to analysis of variance for substrates (Banzatto and Kronka 2006) and then to combined analysis (ANOVA) for experiments (analysis of series of similar experiments). The statistical program Sisvar 5.3 was used (Ferreira 2010), and the means compared by the Tukey test at 5\% probability.

\section{RESULTS AND DISCUSSION}

Temperatures inside and outside of protected environments were similar. A lower vapor pressure deficit was found in the external environment and the environment covered with straw, which are very similar, due to the higher air exchange occurring in these environments (Table 2).

It has been recommended that in combined experiments the relationship between the mean square residues from the individual analyses of variance should not exceed the ratio of approximately 7:1 (Banzatto and Kronka 2006). For the dependent variables of this study, the relations of the mean square residue, except for the number of leaves at 123 DAS (LN5), were lower than 7:1 (Table 3), thus permitting the analysis of experiments and comparison of growth environments.

There was significant interaction between environments and substrates for the variables MET, MER, PH, SD, DMRS, TDM, RHD, RDM, RHDM and DQI (Table 3). Therefore, more emphasis will be given to the effect of interactions on assessed variables.

Table 2 - Temperature $\left({ }^{\circ} \mathrm{C}\right)$, relative humidity (\%) and vapor-pressure deficit (kPa) at $09 \mathrm{~h} 00 \mathrm{~min}, 12 \mathrm{~h} 00 \mathrm{~min}$ and $15 \mathrm{~h} 00$ min for each environment $(\mathrm{A})$ during the experiment. Aquidauana, September 27, 2010 to January 28, 2011.

\begin{tabular}{lllllllllc}
\hline$*$ & \multicolumn{3}{c}{ DBT } & \multicolumn{3}{c}{ RH } & & VPD \\
\hline & $9 \mathrm{hrs}$ & $12 \mathrm{hrs}$ & $15 \mathrm{hrs}$ & $9 \mathrm{hrs}$ & $12 \mathrm{hrs}$ & $15 \mathrm{hrs}$ & $9 \mathrm{hrs}$ & $12 \mathrm{hrs}$ & $15 \mathrm{hrs}$ \\
External & 27.48 & 31.50 & 32.34 & 75.34 & 63.58 & 62.11 & 0.90 & 1.68 & 1.84 \\
Greenhouse & 27.66 & 31.38 & 32.06 & 68.72 & 58.67 & 58.49 & 1.16 & 1.89 & 1.98 \\
Shaded hut & 27.80 & 31.66 & 32.81 & 73.65 & 61.15 & 60.74 & 0.98 & 1.81 & 1.95 \\
Buriti shelter & 27.58 & 31.37 & 32.02 & 75.75 & 65.16 & 64.50 & 0.87 & 1.60 & 1.69 \\
\hline
\end{tabular}

* DBT = dry bulb temperature $\left({ }^{\circ} \mathrm{C}\right) ; \mathrm{RH}=$ relative humidity $(\%) ; \mathrm{VPD}=$ vapor-pressure deficit $(\mathrm{kPa})$. 
Table 3 - Analysis of variance with the calculated $F$, coefficient of variation and ratio between the highest and lowest mean square residue for emergency velocity index (EVI), emergence percentage (EP), mean emergence time (MET), mean emergence rate (MER), plant height (PH) and leaf number (LN) at 63 (AP1, NF1), 78 (AP2: NF2), 93 (AP3; NF3), 108 (AP4; NF4) and 123 (AP5) days after sowing, stem diameter (SD), dry mass of the shoot part (DMAP), dry mass of the root system (DMRS), total dry mass (TDM), ratio of height to diameter (RHD), ratio of shoot dry mass to root dry mass (RDM), ratio of plant height to shoot mass (RHDM) and Dickson quality index (DQI) of genipap. Aquidauana, September 27, 2010 to January $28,2011$.

\begin{tabular}{|c|c|c|c|c|c|c|c|}
\hline & $\mathrm{EVI}$ & EP & MET & MER & $\mathrm{PH} 1$ & $\mathrm{PH} 2$ & $\mathrm{PH} 3$ \\
\hline Ambient & $26.6^{* *}$ & 2.6 NS & $52.1^{* *}$ & 52.0 ** & $2.2^{\mathrm{NS}}$ & $16.7^{\text {** }}$ & $41.4^{* *}$ \\
\hline Substrate & $9.7 * *$ & $4.8 * *$ & $4.1^{*}$ & $4.3 * *$ & 7.2 ** & 3.5 * & 4.6 ** \\
\hline Interaction & 1.9 NS & $2.1^{\mathrm{NS}}$ & 2.3 * & 2.6 * & $1.3^{\mathrm{NS}}$ & 5.2 ** & $3.7^{* *}$ \\
\hline RMSR & 2.56 & 1.96 & 1.71 & 1.57 & 2.57 & 4.99 & 3.18 \\
\hline \multirow[t]{2}{*}{ CV (\%) } & 22.1 & 18.6 & 1.4 & 1.4 & 8.1 & 9.1 & 10.3 \\
\hline & $\mathrm{PH} 4$ & PH5 & LN1 & LN2 & LN3 & LN4 & SD \\
\hline Ambient & 66.0 ** & 59.8 ** & 22.8 ** & $18.1^{\star *}$ & $21.4^{\text {** }}$ & 8.7 ** & 37.8 ** \\
\hline Substrate & 3.8 * & 3.0 * & $0.8^{N S}$ & $2.5^{\mathrm{NS}}$ & 1.7 NS & $2.1^{N S}$ & 2.7 NS \\
\hline Interaction & 0.9 NS & 2.9 * & 0.9 NS & 1.3 NS & $2.1^{\mathrm{NS}}$ & 1.5 NS & 5.0 ** \\
\hline RMSR & 4.33 & 2.97 & 2.73 & 3.3 & 1.26 & 3.26 & 1.16 \\
\hline \multirow[t]{2}{*}{ CV (\%) } & 11.6 & 11.2 & 16.5 & 12.8 & 7.4 & 6.5 & 5.6 \\
\hline & DMAP & DMRS & TDM & RHD & RDM & RHDM & $\mathrm{DQI}$ \\
\hline Ambient & $34.4^{* *}$ & 88.0 ** & 47.6 ** & 38.6 ** & $40.2^{\text {** }}$ & 7.0 ** & 69.7 ** \\
\hline Substrate & 1.4 NS & $2.7 \mathrm{NS}$ & $1.4^{\mathrm{NS}}$ & $2.3^{N S}$ & $8.7^{\star *}$ & $2.5^{\mathrm{NS}}$ & 1.7 NS \\
\hline Interaction & $2.1^{\mathrm{NS}}$ & 3.9 ** & 2.6 * & 3.0 * & 2.7 * & 3.0 * & 3.3 ** \\
\hline RMSR & 3.05 & 4.53 & 3.29 & 2.11 & 2.42 & 2.42 & 4.58 \\
\hline CV (\%) & 20.5 & 18.3 & 19.4 & 9.1 & 11.3 & 26.1 & 19.7 \\
\hline
\end{tabular}

NS $=$ Not significant; ${ }^{*}=$ Significant at $5 \% ;{ }^{* *}=$ Significant at $1 \% ;$ CV $=$ coefficient of variation; RMSR $=$ Relationship between the mean squares of the maximum and minimum residues for the different growth environments.

In the interaction of substrates and growth environments for MER, there was no difference between substrates in the shaded hut and buriti shelter. However in the greenhouse the substrate with mixture of all materials ( $\mathrm{S} 4$ ) promoted a lower MER for seedlings produced in this environment (Table 4).

Among the environments, production in the greenhouse resulted in seedlings with greater MER in substrates S2 and S3 (Table 4). It was observed that seedlings in the nursery with straw roofing buriti shelter had a lower MER for substrates S4, S2 and S1, where in the latter the environment of buriti shelter did not differ from that of greenhouse. Although the environments presented similar temperatures and relative humidities at the moments of harvest (Table 2), the plants presented different emergence behaviors. The faster emergence of seedlings in the greenhouse for some of the substrates may be related to the fact that this stored more energy during the evening period of the experiment so that the seedlings are submitted to temperature conditions more favorable for their emergence.
Besides this, in the greenhouse, the best initial growth of seedlings is related to high light intensity and side protection. Light intensity influenced stomata opening and promoted greater gas exchange and growth (Marenco and Lopes 2009). The side protection promoted by the screen prevented the excessive loss of water due to less wind speed.

Substrates and protected environments that promote faster seedling emergence are beneficial for the formation of seedlings. The longer the emergency, greater is the initial stage of development and at this stage the plants are most susceptible (Martins et al. 1999).

As in the case of the MER, there was no difference in the MET between the substrates in shaded hut and buriti shelter. Inside the greenhouse the substrate $S 4$ promoted seedlings with greater MET than substrates $\mathrm{S} 2$ and $\mathrm{S} 3$ (Table 4). Baron et al. (2011) reported that vermiculite provides a faster emergence rate and consequently lower MET for Araticum-de-Terra-Fria (Rollinia sp.). In the present study, 
Table 4 - Mean emergence rate (MER), mean emergence time (MET), plant height (PH) at 78, 93 and 123 DAS, and stem diameter (SD) of genipap at different environments and substrates. Aquidauana, September 27, 2010 to January 28, 2011.

\begin{tabular}{|c|c|c|c|c|c|c|}
\hline ** & $\mathrm{A} 1$ & $\mathrm{~A} 2$ & A3 & $\mathrm{A} 1$ & $\mathrm{~A} 2$ & A3 \\
\hline & \multicolumn{3}{|c|}{ MER (days ${ }^{-1}$ ) } & \multicolumn{3}{|c|}{ MET (days) } \\
\hline S1 & $0.0315 \mathrm{Aba}^{*}$ & $0.0312 \mathrm{Aa}$ & $0.0303 \mathrm{Ab}$ & $31.73 \mathrm{ABb}$ & $32.10 \mathrm{Ab}$ & $32.96 \mathrm{Aa}$ \\
\hline S2 & $0.0319 \mathrm{Aa}$ & $0.0308 \mathrm{Ab}$ & $0.0300 \mathrm{Ac}$ & $31.38 \mathrm{Bc}$ & $32.47 \mathrm{Ab}$ & $33.36 \mathrm{Aa}$ \\
\hline S3 & $0.0322 \mathrm{Aa}$ & $0.0311 \mathrm{Ab}$ & $0.0306 \mathrm{Ab}$ & $31.11 \mathrm{Bb}$ & $32.11 \mathrm{Aa}$ & $32.63 \mathrm{Aa}$ \\
\hline \multirow[t]{2}{*}{ S4 } & $0.0311 \mathrm{Ba}$ & $0.0311 \mathrm{Aa}$ & $0.0303 \mathrm{Ab}$ & $32.17 \mathrm{Ab}$ & $32.16 \mathrm{Ab}$ & $33.04 \mathrm{Aa}$ \\
\hline & \multicolumn{3}{|c|}{ PH2 (cm) (78 DAS) } & \multicolumn{3}{|c|}{ PH3 (cm) (93 DAS) } \\
\hline S1 & $5.2 \mathrm{Aa}^{*}$ & 4.7 Aab & $4.3 A b$ & $7.7 \mathrm{Aa}$ & $7.3 \mathrm{Aa}$ & $5.7 \mathrm{ABb}$ \\
\hline S2 & $4.3 \mathrm{Ba}$ & $4.5 \mathrm{Aa}$ & $4.5 \mathrm{Aa}$ & $6.8 \mathrm{Aa}$ & $6.5 \mathrm{ABa}$ & $5.9 \mathrm{Aa}$ \\
\hline S3 & $5.4 \mathrm{Aa}$ & $4.2 \mathrm{Ab}$ & $3.6 \mathrm{Bb}$ & $7.7 \mathrm{Aa}$ & $5.7 \mathrm{Bb}$ & $4.6 \mathrm{Bc}$ \\
\hline \multirow[t]{2}{*}{ S4 } & $5.0 \mathrm{ABa}$ & $4.8 \mathrm{Aa}$ & $4.5 \mathrm{Aa}$ & $7.2 \mathrm{Aa}$ & $7.3 \mathrm{Aa}$ & $5.5 \mathrm{ABb}$ \\
\hline & \multicolumn{3}{|c|}{ PH5 (cm) (123 DAS) } & \multicolumn{3}{|c|}{$\mathrm{SD}(\mathrm{mm})$} \\
\hline S1 & $15.9 \mathrm{Aa}$ & $18.0 \mathrm{Aa}$ & $12.9 \mathrm{Ab}$ & $7.0 \mathrm{Aa}^{*}$ & $6.5 \mathrm{ABa}$ & $6.5 \mathrm{Aa}$ \\
\hline S2 & 15.1 Aa & $16.8 \mathrm{ABa}$ & $11.6 \mathrm{Ab}$ & $7.2 \mathrm{Aa}$ & 7.1 Aa & $5.4 \mathrm{Bb}$ \\
\hline S3 & $16.7 \mathrm{Aa}$ & 14.6 Ba & $10.2 A b$ & $7.4 \mathrm{Aa}$ & $5.7 \mathrm{Bb}$ & $5.4 \mathrm{Bb}$ \\
\hline S4 & $15.0 \mathrm{Ab}$ & $18.4 \mathrm{Aa}$ & $11.4 \mathrm{Ac}$ & $7.0 \mathrm{Aa}$ & $6.7 \mathrm{Aa}$ & $5.1 \mathrm{Bb}$ \\
\hline
\end{tabular}

* Equal upper-case letters in the columns and lower-case letters in the lines do not differ by the Tukey test at $5 \%$ probability. ** $\mathrm{S} 1=50 \%$ cattle manure $+50 \%$ cassava foliage; $S 2=50 \%$ cattle manure $+50 \%$ Vida Verde ${ }^{\oplus} ; S 3=50 \%$ cattle manure $+50 \%$ vermiculite; $S 4=25 \%$ cattle manure $+25 \%$ cassava foliage $+25 \%$ Vida Verde ${ }^{\circledast}+25 \%$ vermiculite; $\mathrm{A} 1$ = Greenhouse; $\mathrm{A} 2$ = Shaded hut; $\mathrm{A} 3=$ Buriti shelter

the increased percentage of vermiculite in substrate $S 3(50 \%)$ probably favored the emergence of seedlings in the greenhouse.

In the buriti shelter resulted in seedlings with higher MET for all substrates with the exception of S3, where seedlings in this environment did not differ from shaded hut (Table 4).

In measuring plant height at 78 DAS, substrates S3 and S1 promoted seedlings taller than those from the substrate S2 within greenhouse (Table 4). For the buriti shelter, the substrate with cattle manure and vermiculite (S3) resulted in shorter plants and in shaded hut there was no difference between the substrates. Inside greenhouse at 93 DAS (PH3) and 123 DAS (PH5) and in the buriti shelter at 123 DAS, the substrates led to smaller seedlings. Substrate S3 resulted in the smallest seedlings in shaded hut at 93 and 123 DAS, with the exception of substrate S2 which did not differ from S3. In environment buriti shelter at 93 DAS the substrate (S2) favored seedling production, since it resulted in taller plants when compared with the substrate S3.

Plant height is useful parameter, since it not only allow to assess seedlings quality, but it is also is a parameter easy to be measured and is not a destructive procedure (Gomes et al. 2002). Costa et al. (2005) found that five months after transplanting, substrates based on cattle manure (manure + black earth, 1:1 ratio; and black soil + carbonized rice hulls + cattle manure, 1:1:1 ratio) led to taller genipap plants, than plant height we reported in this study. Mesquita et al. (2009) also recommend a substrate containing cattle manure in its composition to obtain tall plants of genipap.

For comparison of environments for each substrate it was observed that the greenhouse produced the tallest genipap seedlings in substrate S3 at 78 and 93 DAS (Table 4). At 78 DAS the plants showed a greater height in the greenhouse in relation only to the buriti shelter for the substrate $S 1$.

The buriti shelter produced smaller seedlings with lower average heights in relation to other environments for the substrates S1, S3 and S4 at 93 DAS, and in all substrates at 123 DAS. In the last measurement of height at 123 DAS, the seedlings in shaded hut were taller in relation to the other environments for the substrate S4 (Table 4).

In the buriti shelter, more damage to the leaves was observed which probably led to lower values of plant height, as indicated in Table 4. Lateral screens are an alternative for the protection of plants against insects.

Substrates S2 and S4 induced thicker stems than substrate S3 within shaded hut. In buriti shelter, the substrate S1 induced seedlings with greater stem diameter than the others. Mesquita et al. (2009) found favorable results of SD for genipap when using a substrate composed of soil, manure 
and coconut dust as an alternative material with recipients composed of plastic bags, however the SD found by those authors was less than that in the present experiment.

Within buriti shelter, $\mathrm{S} 4$ was more efficient than the others with respect to dry mass of the root system (DMRS) (Table 5). Similar results were found by Costa et al. (2005) using substrates composed of black soil + manure (1:1) and black soil + carbonized rice hulls + cattle manure $(1: 1: 1)$ at five months after transplanting. Vermiculite present in substrate S4 (25\%) may have favored the chemical and physical conditions of the substrate, since this type 2:1 clay mineral is characterized by promoting greater cation exchange and promotes lower soil density (Martin et al. 2006). Lower density is interesting because it allows root development with less restriction.

With respect to the total dry mass (TDM), substrate $S 4$ induced seedlings with TDM only greater than the substrate S2 within buriti shelter (Table 5). It is likely that the presence of cattle manure and vermiculite in the proportion of $25 \%$ resulted in the improved characteristics of substrate S4. The different substrates in greenhouse did not differ with regards to $\mathrm{SD}$, or in greenhouse and shaded hut for the DMRS and TDM.

Regarding the environment for the different substrates, the greenhouse showed a greater efficiency since it resulted in seedlings with greater $\mathrm{SD}$ in substrate $\mathrm{S} 3$ (Table 4 ) and greater DMRS and TDM within of the substrates S1 and S2 (Table 5). Higher light intensity often results in a higher accumulation of biomass (Marenco and Lopes 2009).

For substrate $S 4$ the plants in the greenhouse were greater only than those in buriti shelter when comparing SD and DMRS. There is a clear interaction between environments and substrates factors, since not all substrates had the same behavior in the growth environments. Probably the different types of covering materials established different intensities of PAR in plants depending on the type of substrate used, and consequently plant growth.

Overall the nursery covered with straw was not suitable for the variables of SD, DMRS and TDM, resulting in seedlings with lower results of SD in S2 and S4, and DMRS and TDM in S1, S2 and S3 (Table 5), which again indicates the negative effect of the absence of lateral screens, and most likely reduced light intensity. With respect to SD for substrate S1 and TDM for substrate S4, the environments did not differ.

Regarding the ratio of shoot height to diameter (RHD) (Table 5) there was a difference between the substrates only in the nurseries, where substrate $S 2$ in the shaded hut induced seedlings with lower RHD than S1 and S4, and substrate S3 in the buriti shelter induced seedlings with lower RHD than

Table 5 - Ratio of height to diameter (RHD), ratio of dry shoot mass to root mass (RDM), ratio of height to dry shoot mass (RHDM) and Dickson quality index (DQI) of genipap at 123 DAS at different environments and substrates. Aquidauana, September 27, 2010 to January $28,2011$.

\begin{tabular}{|c|c|c|c|c|c|c|}
\hline & \multicolumn{3}{|c|}{ DMRS (g) } & \multicolumn{3}{|c|}{ TDM (g) } \\
\hline ** & $\mathrm{A} 1$ & $\mathrm{~A} 2$ & A3 & $\mathrm{A} 1$ & $\mathrm{~A} 2$ & A3 \\
\hline S1 & $1.77 \mathrm{Aa}$ & $1.32 \mathrm{Ab}$ & $0.65 \mathrm{Bc}$ & $6.95 \mathrm{Aa}$ & $5.13 \mathrm{Ab}$ & $3.26 \mathrm{ABC}$ \\
\hline S2 & $2.00 \mathrm{Aa}$ & $1.29 \mathrm{Ab}$ & $0.56 \mathrm{Bc}$ & $6.75 \mathrm{Aa}$ & $4.88 \mathrm{Ab}$ & $2.50 \mathrm{Bc}$ \\
\hline S3 & $1.74 \mathrm{Aa}$ & $1.44 \mathrm{Aa}$ & $0.69 \mathrm{Bb}$ & $6.15 \mathrm{Aa}$ & $5.60 \mathrm{Aa}$ & $3.23 \mathrm{ABb}$ \\
\hline \multirow[t]{2}{*}{ S4 } & $1.69 \mathrm{Aa}$ & 1.49 Aab & $1.25 \mathrm{Ab}$ & $6.00 \mathrm{Aa}$ & $5.47 \mathrm{Aa}$ & $4.83 \mathrm{Aa}$ \\
\hline & \multicolumn{3}{|c|}{$\mathrm{RHD}\left(\mathrm{cm} \cdot \mathrm{mm}^{-1}\right)$} & \multicolumn{3}{|c|}{ RDM $\left(g \cdot g^{-1}\right)$} \\
\hline S1 & $2.30 A b^{\star}$ & $2.79 \mathrm{Aa}$ & $1.96 \mathrm{Abc}$ & $2.91 \mathrm{Ab}$ & $2.95 \mathrm{Ab}$ & $4.07 \mathrm{Aa}$ \\
\hline S2 & $2.11 \mathrm{Aa}$ & 2.37 Ba & $2.15 \mathrm{Aba}$ & $2.38 \mathrm{Ab}$ & $2.86 \mathrm{Ab}$ & $3.46 \mathrm{Ba}$ \\
\hline S3 & $2.27 \mathrm{Aa}$ & $2.56 \mathrm{ABa}$ & $1.89 \mathrm{Bb}$ & $2.53 \mathrm{Ab}$ & $2.90 \mathrm{Ab}$ & $3.69 \mathrm{Aba}$ \\
\hline \multirow[t]{2}{*}{ S4 } & $2.13 \mathrm{Ab}$ & $2.76 \mathrm{Aa}$ & $2.25 \mathrm{Ab}$ & $2.56 \mathrm{Aa}$ & $2.67 \mathrm{Aa}$ & $2.86 \mathrm{Ca}$ \\
\hline & \multicolumn{3}{|c|}{ RHDM $\left(\mathrm{cm} \cdot \mathrm{g}^{-1}\right)$} & \multicolumn{3}{|c|}{ DQI } \\
\hline S1 & $3.22 A b$ & 4.81 Aab & $5.26 \mathrm{Aba}$ & $1.34 \mathrm{Aa}$ & $0.90 \mathrm{Ab}$ & $0.54 \mathrm{Bc}$ \\
\hline S2 & $3.29 \mathrm{Ab}$ & $4.97 \mathrm{Aab}$ & $6.11 \mathrm{Aa}$ & $1.50 \mathrm{Aa}$ & $0.95 \mathrm{Ab}$ & $0.45 \mathrm{Bc}$ \\
\hline S3 & $3.98 \mathrm{Aa}$ & $3.61 \mathrm{Aa}$ & 4.10 BCa & $1.28 \mathrm{Aa}$ & $1.03 \mathrm{Aa}$ & $0.58 \mathrm{Bb}$ \\
\hline S4 & $3.47 \mathrm{Aa}$ & $4.78 \mathrm{Aa}$ & $3.30 \mathrm{Ca}$ & $1.28 \mathrm{Aa}$ & $1.01 \mathrm{Aab}$ & $0.94 \mathrm{Ab}$ \\
\hline
\end{tabular}

* Equal upper-case letters in the columns and lower-case letters in the lines do not differ by the Tukey test at $5 \%$ probability. ** $\mathrm{S} 1=50 \%$ cattle manure $+50 \%$ cassava foliage; $\mathrm{S} 2=50 \%$ cattle manure $+50 \%$ Vida Verde ${ }^{\circledR} ; \mathrm{S} 3=50 \%$ cattle manure $+50 \%$ vermiculite; $S 4=25 \%$ cattle manure $+25 \%$ cassava foliage $+25 \%$ Vida Verde ${ }^{\circledR}+25 \%$ vermiculite; $\mathrm{A} 1$ = Greenhouse; $\mathrm{A} 2$ = Shaded hut; $\mathrm{A} 3$ = Buriti shelter. 
S4. A nursery covered with Sombrite observed lower RHD for Hymenaea stigonocarpa when using a vermiculite-based substrate (Costa et al. 2011a).

The shoot height and stem diameter, as well as ratio between these two variables (RHD), are morphological characteristics used to assess the quality of tree seedlings (Chaves and Paiva 2004). This parameter allows for evaluation of forest seedlings without the need for their destruction (Gomes et al. (2002). For this reason, seedling quality decreases as with smaller values obtained, since tall seedlings with low stem diameter present a greater risk of falling in the field (Reis et al. 2008).

For the environments with different substrates, the seedlings in the shaded hut had higher RHD than the others in substrates S1 and S4 (Table 5). The monofilament screen presented seedlings with higher RHD using soil as substrate for Hymenaea stigonocarpa (Costa et al. 2011a). Regarding substrates $S 3$ and $S 1$, the buriti shelter induced seedlings with lower RHD than the others. The same authors observed higher RHD for seedlings in greenhouse with substrates containing Plantmax.

For the ratio of shoot dry matter to dry root matter (RDM), there was no difference between substrates in the greenhouse and shaded hut (Table 5). In buriti shelter, the substrate S4 with 25\% cassava foliage promoted plants with lower RDM and closer to 2 than the others. With regard to the different environments, only substrate S4 showed no difference between the environments, in the other substrates of the greenhouse and shaded hut presented seedlings with lower RDM and closer to 2 .

Interactions of the ratio of height to dry mass of the shoot portion (RHDM) revealed no differences among substrates in the greenhouse and shaded hut (Table 5). For the substrates this effect was observed only in buriti shelter, where substrate S4 promoted lower RHDM than substrates S1 and S2. For the seedlings to express the greatest potential for survival, they should present low RHDM values (Gomes 2001). For formation of Eucalyptus grandis seedlings this index presented satisfactory results for quality assessment (Gomes et al. 2002).

The RHDM is a very important index for evaluation of seedlings since it indicates the possible survival of seedlings in the field (Gomes 2001). For comparison of environments in the different substrates, the seedlings in greenhouse were lower in terms of the absolute RHDM values only when compared to the buriti shelter in substrates $S 1$ and S2. In the other substrates, there was no difference among the environments (Table 5).

For the DQI there was no difference between the substrates in the greenhouse and shaded hut (Table 5). In the nursery covered with straw the substrate $\$ 4$, composed of cassava foliage in the volumetric ratio of $25 \%$, showed to be favorable to the seedlings. Cassava foliage present in the substrate can reduce costs of this formulation because it is a material widely available in the region.

The buriti shelter induced seedlings with the lowest DQI in all substrates, except for $\mathrm{S} 4$ which did not differ from shaded hut, again highlighting the likely depressive effect caused by either unprotected lateral openings or low light. The opposite was observed in greenhouse which presented seedlings with the highest DQI among all substrates, where for S3 and S4 the greenhouse did not differ from shaded hut (Table 5). The better DQI values for Hymenaea stigonocarpa was found in an environment covered with polyethylene film associated with a coconut fiber substrate (Costa et al. (2011a).

The analysis revealed that for the isolated effects of protected environments the seedlings in the agricultural greenhouse stood out with regards to the variables EVI, LN1 (63 DAS), LN2 (78 DAS) and DMAP, where for LN1 and DMAP the lowest absolute values were acquired in the nursery covered with straw (Table 6). These results demonstrate,

Table 6 - Isolated effects of the environments and substrates for the emergence velocity index (EVI), emergence percentage (EP), plant height (PH) (cm) at 63 and 108 DAS, leaf number (LN) at 63, 78, 93 and 108 DAS and dry mass of the shoot (DMAP) (g) of genipap. Aquidauana, September 27, 2010 to January 28,2011

\begin{tabular}{lcccccccccc}
\hline$* *$ & EVI & EP & PH1 & PH 4 & LN1 & LN2 & LN3 & LN4 & DMAP \\
\hline A1 & $2.06 \mathrm{~A} *$ & $85.0 \mathrm{~A}$ & $3.1 \mathrm{~A}$ & $10.0 \mathrm{~B}$ & $3.5 \mathrm{~A}$ & $5.7 \mathrm{~A}$ & $7.7 \mathrm{~A}$ & $9.3 \mathrm{~A}$ & $4.7 \mathrm{~A}$ \\
$\mathrm{~A} 2$ & $1.52 \mathrm{~B}$ & $77.0 \mathrm{~A}$ & $3.0 \mathrm{~A}$ & $11.5 \mathrm{~A}$ & $3.0 \mathrm{~B}$ & $4.7 \mathrm{~B}$ & $7.3 \mathrm{~A}$ & $9.0 \mathrm{~A}$ & $3.9 \mathrm{~B}$ \\
$\mathrm{~A} 3$ & $1.26 \mathrm{~B}$ & $75.0 \mathrm{~A}$ & $3.0 \mathrm{~A}$ & $7.5 \mathrm{C}$ & $2.5 \mathrm{C}$ & $4.5 \mathrm{~B}$ & $6.6 \mathrm{~B}$ & $8.5 \mathrm{~B}$ & $2.7 \mathrm{C}$ \\
$\mathrm{S} 1$ & $1.87 \mathrm{~A}$ & $86.7 \mathrm{~A}$ & $3.1 \mathrm{AB}$ & $10.4 \mathrm{~A}$ & $3.1 \mathrm{~A}$ & $5.2 \mathrm{~A}$ & $7.3 \mathrm{~A}$ & $9.2 \mathrm{~A}$ & $3.9 \mathrm{~A}$ \\
$\mathrm{~S} 2$ & $1.29 \mathrm{~B}$ & $67.3 \mathrm{~B}$ & $2.9 \mathrm{BC}$ & $9.4 \mathrm{AB}$ & $2.8 \mathrm{~A}$ & $4.8 \mathrm{~A}$ & $7.2 \mathrm{~A}$ & $8.8 \mathrm{~A}$ & $3.4 \mathrm{~A}$ \\
$\mathrm{~S} 3$ & $1.84 \mathrm{~A}$ & $82.7 \mathrm{~A}$ & $2.8 \mathrm{C}$ & $9.1 \mathrm{~B}$ & $3.0 \mathrm{~A}$ & $4.6 \mathrm{~A}$ & $6.9 \mathrm{~A}$ & $8.8 \mathrm{~A}$ & $3.7 \mathrm{~A}$ \\
$\mathrm{~S} 4$ & $1.46 \mathrm{~B}$ & $79.3 \mathrm{AB}$ & $3.2 \mathrm{~A}$ & $9.7 \mathrm{AB}$ & $3.0 \mathrm{~A}$ & $5.2 \mathrm{~A}$ & $7.2 \mathrm{~A}$ & $9.0 \mathrm{~A}$ & $4.0 \mathrm{~A}$ \\
\hline
\end{tabular}

* Equal letters in the column do not differ by the Tukey test at $5 \%$ probability. ** $\mathrm{S} 1=50 \%$ cattle manure $+50 \%$ cassava foliage; $\mathrm{S} 2=50 \%$ cattle manure $+50 \%$ Vida Verde ${ }^{\circledR}$; $\mathrm{S} 3=50 \%$ cattle manure $+50 \%$ vermiculite; $\mathrm{S} 4=25 \%$ cattle manure $+25 \%$ cassava foliage $+25 \%$ Vida Verde ${ }^{\circledR}+25 \%$ vermiculite; $A 1=$ Greenhouse; $A 2=$ Shaded hut; $A 3$ $=$ Buriti shelter. 
despite the genipap provide adaptation to different types of greenhouses, the combination of polyethylene film and thermal reflector screen increased the availability of active photosynthetically radiation and favored greater accumulation of biomass, which is consistent with Lima et al. (2010) whose observed in three tree species, higher accumulation of biomass with greater availability of light.

When comparing only the nurseries for PH4 (108 DAS), shaded hut promoted plants with higher average height than buriti shelter. For LN3 (93 DAS) and LN4 (108 DAS), greenhouse and shaded hut did not differ but both showed to be higher than buriti shelter. With regard to the EP and PH1 (63 DAS) all environments were similar.

With respect to the isolated effects of the substrates, seedlings in substrates S1 and S3 did not differ and were superior to the substrates S2 and S4 in terms of EVI (Table 6). It is possible that the lower EVI values encountered for substrates S2 and S4 are linked to the presence of Vida Verde in both, because The commercial substrates Bioplant and Plugmix presented lower EVI values for seedlings of Mulungu (Erythrina velutina Willd), and this effect may be due to the fact that these do not promote proper conditions of aeration and moisture (Alves et al. 2008).

Substrates S1 and S3 favored seedlings with regards to the emergence percentage (EP) and were superior only to S2 (Table 6). Substrate $S 1$ and S3 probably increased porosity, favored higher change of air and water and accelerated the emergency in these substrates, since, at this stage, there is no high nutritional need by the seedlings (Nogueira et al. 2003). Studies about the effect of substrates on emergence of Erythrina velutina Willd seedlings, found that the commercial substrates Bioplant and Plugmix was not favorable to emergence percentage (Alves et al. 2008); these values are higher than those encountered in the present experiment for the $\mathrm{S} 2$.

Substrate $S 4$ promoted greater plant height at 63 DAS (PH1) when compared with substrates S2 and S3 (Table 6). For PH4 substrate S1 induced greater average height only with respect to S3. For the attributes LN1, LN2, LN3, LN4 and DMAP there was no effect of substrates. However, it was observed that the number of leaves was much higher than that found by Mesquita et al. (2009) for genipap in a substrate formulated with soil + manure + coconut powder $(1: 1: 1)$.

\section{CONCLUSIONS}

In the greenhouse, it is indicated to use substrates 50\% cattle manure $+50 \%$ cassava foliage and $50 \%$ cattle manure $+50 \%$ Vida Verde.

In the shaded hut, the following substrates can be used: S3 (50\% cattle manure $+50 \%$ vermiculite) and S4 (25\% cattle manure $+25 \%$ cassava foliage $+25 \%$ Vida Verde + $25 \%$ vermiculite).

The buriti shelter is not indicated for the formation of genipap seedlings.

\section{ACKNOWLEDGMENTS}

To the CNPq for the Master's scholarship provided to the first author.

\section{REFERENCES}

Alves, E.U.; Andrade, L.A.; Barros, H.H.A.; Gonçalves, E.P.; Alves, A.U.; Gonçalves, G.S.; Oliveira, L.S.B.; Cardoso, E.A. 2008. Substratos para testes de emergência de plântulas e vigor de sementes de Erythrina velutina Willd, Fabaceae. Semina: Ciências Agrárias, 29: 69-82.

Andrade, A.C.S; Souza, A.F.; Ramos, F.N.; Pereira, T.S.; Cruz, A.P.M. 2000. Germinação de sementes de jenipapo: temperatura, substrato e morfologia do desenvolvimento pós-seminal. Pesquisa Agropecuária Brasileira, 35: 609-615.

Banzatto, D.A.; Kronka, S.N. 2006. Experimentação agrícola. 3. ed. Jaboticabal, Funep. 237 pp.

Baron, D.; Ferreira, G.; Boaro, C.S.F.; Mischan, M.M. 2011. Evaluation of substrates on the emergence of "Araticum-deterra-fria” (Annonae marginata (Schltdl.) H. Rainer) seedlings. Revista Brasileira de Fruticultura, 33: 575-586.

Chaves, A.S.; Paiva, H.N. 2004 Influência de diferentes períodos de sombreamento sobre a qualidade de mudas de fedegoso (Senna macranthera (Collad.) Irwin et Barn.). Scientia Forestalis, 65: 22-29.

Costa, E.; Durante, L.G.Y.; Nagel, P.L.; Ferreira, C.R.; Santos, A. 2011b. Qualidade de mudas de berinjela submetida a diferentes métodos de produção. Revista Ciência Agronômica, 42: 10171025 .

Costa, E.; Leal, P.A.M.; Rego, N H.; Benatti, J. 2011 a. Desenvolvimento inicial de mudas de jatobazeiro do cerrado em Aquidauana-MS. Revista Brasileira de Fruticultura, 33: 215-226.

Costa, M.C.; Figueiredo, M.C.; Albrecht, J.M.F.; Coelho, M.F.B. 2005. Substratos para produção de mudas de jenipapo (Genipa americana L.). Pesquisa Agropecuária Tropical, 35: 19-24, 2005.

Ferreira, D.F. 2010. Sisvar - Sistema de análise de variância. Versão 5.3. Universidade Federal de Lavras, Lavras-MG.

Ferreira, W.R.; Ranal, M. Dorneles, M.C., Santana, D.G. 2007. Crescimento de mudas de Genipa americana L. submetidas a condiçôes de pré-semeadura. Revista Brasileira de Biociências, 5: $1026-1028$.

Gomes, J.M. 2001. Parâmetros morfológicos na avaliação da qualidade de mudas de Eucalyptus grandis, produzidas em diferentes tamanhos de tubete e de dosagens de N-P-K. Tese de Doutorado em Ciência Florestal, Universidade Federal de Viçosa, Viçosa. 126 pp.

Gomes, J.M.; Couto, L.; Leite, H.G.; Xavier, A.; Garcia, S.L.R. 2002. Parâmetros morfológicos na avaliaçáo da qualidade de Eucalyptus grandis. Revista Árvore, 26: 655-664. 
Lima, M.A.O.; Mielke, M.S.; Lavinsky, A.O.; França, S.; Almeida, A.A.F.; Gomes, F. P. 2010. Crescimento e plasticidade fenotípica de três espécies arbóreas com uso potencial em sistemas agroflorestais. Scientia Forestalis, 38: 527:534.

Lorenzi, H. 2000. Árvores brasileiras: manual de identificação e cultivo de plantas arbóreas nativas do Brasil. 3. ed. Instituto Plantarum, Nova Odessa, SP. 384 pp.

Marenco, R.A., Lopes, N.F. 2009. Fisiologia vegetal: Fotossíntese, respiração, relações hídricas e nutrição mineral. 3. ed. Viçosa: Editora UFV. 486 pp.

Martin, T.N.; Lima, L.B.; Rodrigues, A.; Girardi, E.; Fabri, E.G.; Minami, K. 2006. Utilização de vermiculita, casca de pínus e carvão na produção de mudas de pepino e pimentão. Acta Scientiarum. Agronomy, 28: 107-113.

Martins, C.C.; Nakagawa, J.; Bovi, M.L.A. 1999. Efeito da posição da semente no substrato e no crescimento inicial das plântulas de palmito-vermelho (Euterpe espiritosantensis Fernandes PALMAE. Revista Brasileira de Sementes, 21: 164-173.

Mesquita, J.B.; Santos, M.J.C.; Ribeiro, G.T.; Moura, A.O. 2009. Avaliação da composição de substratos em recipientes na produção de mudas de jenipapo (Genipa americana L.). Acta Forestalis, 1: 47-58.
Nascimento, W.M.O.; Carvalho, N.M. 1998. Determinação da viabilidade de sementes de jenipapo (Genipa americana L.) através do teste de tetrazólio. Revista Brasileira de Sementes, 20: 231-235.

Nogueira, R.J.M.C.; Albuquerque, M.B.; Silva Junior, J.F. 2003. Efeito do substrato na emergência, crescimento e comportamento estomático em plântulas de mangabeira. Revista Brasileira de Fruticultura, 25: 15-18.

Reis, E.R.; Lúcio, A.D.C.; Fortes, F.O.; Lopes, S.J.; Silveira, B.D. 2008. Período de permanência de mudas de Eucalyptus grandis em viveiro baseado em parâmetros morfológicos. Revista Árvore, 32: 809-814.

Rizzini, C.T.; Mors, W.B. 1995. Botânica econômica brasileira. 2. ed. Âmbito Cultural, Rio de Janeiro, RJ. 248 pp.

Souza, C.N. 2007. Características, físicas, fisico-químico e químicas de três tipos de jenipapos (Genipa americana L.). Dissertação de Mestrado em Agronomia, Produção vegetal, Universidade Estadual de Santa Cruz, Ilheus-Bahia. 58 pp.

Recebido em:05/01/2012

Aceito em: 05/05/2012 